\title{
AN INVESTIGATION OF BLOOD LOSS DURING OPERATIONS ON THE NEWBORN INFANT
}

\author{
BY \\ P. P. RICKHAM \\ From the Department of Child Health, University of Liverpool
}

(RECEIVED FOR PUBLICATION MARCH 8, 1954)

In recent years surgical conditions in newborn babies have aroused considerable interest and the scope of operative procedures in this age group has been greatly extended. Operations of considerable magnitude are now being successfully undertaken and surgeons are faced with the problem of blood replacement during and after these operations. In a newborn infant the difference between undertransfusion and over-transfusion might be a matter of only a few millilitres, and it is therefore desirable to have some exact information about the amount of blood lost during operation. A consecutive series of 60 newborn babies undergoing operations in the Neonatal Surgical Unit at Alder Hey Children's Hospital has been investigated with the following aims: (1) To discover the most satisfactory method of estimating blood loss during operation; (2) to obtain some idea of the average blood loss in different types of operation; (3) to try to gauge how accurately blood should be replaced.

\section{Methods for Investigating Blood Loss}

Gatch and Little (1924) were the first to estimate blood loss during operation. They soaked the blood-stained swabs in a solution of $0.1 \%$ hydrochloric acid, and the haemoglobin concentration of the washings was determined by colorimeter. This method has an experimental error of at least $13 \%$ (White and Buxton, 1942). Wangensteen (1942) used a gravimetric method. He weighed the bloodsoaked sponges used at operation, but, because of practical difficulties, he omitted to weigh the bloodsoiled towels, gowns, etc. He compensated for this error by adding about $200 \mathrm{ml}$. to the estimated blood loss. Occasionally Wangensteen used wet sponges in addition to dry ones but did not include these in his weighings. There was therefore a considerable error in his calculations. Bonica and Lyter (1951) modified this method by using swabs which were moistened with saline poured from a sterile measuring cylinder. They could therefore include the moist swabs in their final calculations of the blood loss. These two methods, colorimetric and gravimetric, have been used by all subsequent investigators with only minor modifications. The colorimetric method has been made more accurate by the introduction of photoelectric haemoglobin estimations (Pilcher and Sheard, 1937; Coller, Crook and Iob, 1944).

\section{Physiological Considerations}

For both adults and newborn infants the mean blood volume is approximately $85 \mathrm{ml}$. per $\mathrm{kg}$. of body weight (Mollison, Veall and Cutbush, 1950). The blood volume of the normal adult male is in the neighbourhood of $6,000 \mathrm{ml}$., while the normal newborn baby weighing $6 \frac{1}{2} \mathrm{lb}$. has a blood volume of approximately $250 \mathrm{ml}$., or roughly $\frac{1}{24}$ that of the adult.

Leriche and Vasilaros (1939) thought that an adult patient in fairly good health could safely stand a loss of $500 \mathrm{ml}$. of blood, and Gatch and Little (1924) believed that a loss of $700 \mathrm{ml}$. could be well tolerated. There is therefore a considerable margin of safety. In the newborn infant, however, a blood loss at operation of as little as 20 to $30 \mathrm{ml}$. might be of significance, and accurate methods in determining the blood loss and calculating blood replacement must be employed.

\section{Plan of Investigation}

In most of the operations under investigation the gravimetric and colorimetric methods were used side by side. (Similar comparative studies in adults were carried out by Baronofsky, Treloar, and Wangensteen in 1946.) In just under one-third of the operations the gravimetric method was not used, because the excessive amount of other fluids lost during operation would have falsified the result.

Gravimetric Method. The method outlined below is more complicated than the method previously described by American workers. In America swabs used in the 
operation theatres are machine-cut and of uniform size and weight so the American workers could dispense with weighing the swabs before operation. In this country the swabs are usually cut by hand and vary greatly in size and weight.

A weighing machine accurate to $0.2 \mathrm{~g}$. was used. Several dozen dry, sterile swabs were weighed before operation and the weight recorded. As soon as swabs became blood-stained during operation they were collected and weighed. Because it might be argued that the loss of weight by evaporation of moisture from the blood-soaked swabs would introduce an error, one dozen swabs were soaked individually with varying measured amounts of blood and left to dry for 20 minutes in an atmosphere of $78^{\circ} \mathrm{F}$. temperature and $48 \%$ humidity. Even under these conditions the loss of weight was found to be under $1 \%$. When moist swabs were needed during operation the swabs were moistened with accurately measured amounts of sterile saline. After operation the remaining unused swabs were weighed.

The total weight of the swabs soiled (s.S.) and unsoiled (u.s.S.) minus the weight of the swabs before operation (S.) and the weight of saline used for moistening the swabs (W.) equalled the weight of the blood lost. The weight in grams divided by 1.06 (mean specific gravity of blood) gave the amount of blood lost in millilitres,

$$
\text { Blood lost }=\frac{\text { s.S. }+ \text { u.s.S. }-(\text { S. }+ \text { W. })}{1.06}
$$

The accuracy of this method was checked repeatedly by weighing bundles of swabs moistened with measured amounts of blood.

Colorimetric Method. After the blood-soiled swabs had been weighed they were immediately immersed in a bowl of water. Gowns and towels soiled at operation were washed in water and this water was added to the contents of the bowl. The swabs were removed from the bowl, wrung out and immersed in another bowl filled with clear water. This procedure was repeated until the rinsing water remained perfectly clear. All the washings were mixed and their volume measured. The haemoglobin concentration was then estimated using the Medical Research Council gray-wedge photometer. The haemoglobin concentration of the infant's blood was determined from capillary samples immediately before and after operation. Care was taken that the same person performed all haemoglobin estimations and that the samples were obtained from free flowing blood.

Previous investigators used to take only a preoperative sample of haemoglobin and regarded this as a valid measure of the patient's haemoglobin concentration during operation. While this may be accurate when the blood loss is insignificant or when the blood replaced by transfusion has a haemoglobin concentration similar to that of the patient, it would be quite inaccurate in neonates. In newborn infants the haemoglobin concentration is much higher than that of the blood used for transfusions. During operation the haemoglobin level will therefore decrease in spite of the fact that replacement transfusions have been performed. In this investigation the haemoglobin concentration in the patient's blood was accordingly taken as the mean value of the pre- and post-operative haemoglobin reading. It must, however, be admitted that the pre-operative haemoglobin reading was more accurate than the post-operative value. This was due to the fact that it was more difficult to obtain satisfactory samples of blood from some of the patients, who were shocked after a prolonged operation.

Knowing the patient's haemoglobin concentration (Hb.P.), the total volume (V.) and the haemoglobin concentration of the water used for rinsing the swabs (Hb.W.), and bearing in mind that the haemoglobin concentration of the water was directly estimated while the haemoglobin concentration of the blood was estimated after diluting the blood 1 in 200 , it was possible to calculate the amount of blood lost by this formula:

$$
\text { Blood loss }=\frac{\text { V. } \times \text { Hb.W. }}{\text { Hb.P. } \times 200}
$$

The accuracy of the extraction technique was repeatedly checked using swabs moistened with a measured amount of blood.

\section{Results}

The results obtained in the study of 60 patients are shown in Table 1 . It will be observed that in 17 patients the blood loss was not estimated gravimetrically. The reason for this omission has been already mentioned. In one patient the colorimetric method was not used as it was found impossible to obtain an adequate post-operative haemoglobin reading.

\section{Discussion}

Blood loss during operations on adults has been measured by many observers and all types of surgical procedures have been studied. Bonica and Lyter (1951) reviewed more than 1,700 cases reported in the American literature. There is, however, only one report of the amount of blood lost during an operation on an infant of 2 months of age (White and Buxton, 1942) and blood loss in newborn babies has apparently not been studied. The present investigation was therefore handicapped by the fact that no comparable figures were available.

Most Satisfactory Method of Estimating Blood Loss in the Newborn. While the majority of workers investigating blood loss in adults have preferred the gravimetric method, we have found that in the newborn the colorimetric technique offers several advantages.

Baronofsky et al. (1946) noted that in adults the amount of blood lost estimated gravimetrically was about $10 \%$ higher than the colorimetric values. There was an even greater difference in our cases. This might be explained in part by the greater 
TABLE 1

RESULTS IN 60 PATIENTS

\begin{tabular}{|c|c|c|c|c|c|c|c|c|}
\hline Initials & $\begin{array}{l}\text { Wei } \\
(\mathrm{lb} \text {. }\end{array}$ & $\begin{array}{l}\text { ight } \\
\text { oz.) }\end{array}$ & $\begin{array}{c}\text { Pre- } \\
\text { operative } \\
\text { Hb. (\%) }\end{array}$ & $\begin{array}{c}\text { Post- } \\
\text { operative } \\
\text { Hb. (\%) }\end{array}$ & $\begin{array}{c}\text { Gravimetric } \\
\text { Blood Loss } \\
\text { (ml.) }\end{array}$ & \begin{tabular}{|c|}
$\begin{array}{c}\text { Colorimetric } \\
\text { Blood Loss } \\
(\mathrm{ml} .)\end{array}$ \\
\end{tabular} & $\begin{array}{c}\text { Blood } \\
\text { Transfused } \\
\text { (ml.) }\end{array}$ & Remarks \\
\hline $\begin{array}{l}\text { B.P. } \\
\text { L.B. } \\
\text { P.H. } \\
\text { K.B. } \\
\text { W.M. } \\
\text { P.H. } \\
\text { J.A. }\end{array}$ & $\begin{array}{l}4 \\
6 \\
4 \\
6 \\
4 \\
4 \\
3 \\
5\end{array}$ & $\begin{array}{r}8 \\
3 \\
11 \\
9 \\
10 \\
4\end{array}$ & $\begin{array}{l}152 \\
165 \\
154 \\
130 \\
146 \\
133 \\
130\end{array}$ & $\begin{array}{l}152 \\
145 \\
166 \\
130 \\
120 \\
140 \\
124\end{array}$ & $\begin{array}{l}19 \cdot 3 \\
32 \cdot 8 \\
15 \cdot 5 \\
14 \cdot 6 \\
13 \cdot 3 \\
31 \cdot 5\end{array}$ & $\begin{array}{l}16 \\
24 \cdot 4 \\
15 \cdot 1 \\
7 \cdot 5 \\
7 \cdot 4 \\
5 \\
34\end{array}$ & $\begin{array}{l}50 \\
60 \\
64 \\
25 \\
50 \\
36\end{array}$ & $\begin{array}{l}\text { Oesophageal Atresia } \\
\text { Chest filled with water to test anastomosis } \\
\text { Chest filled with water to test anastomosis } \\
\text { Chest filled with water to test anastomosis } \\
\text { Blood spilt on towels }\end{array}$ \\
\hline B.M. & 5 & 6 & 144 & 140 & - & $4 \cdot 6$ & 一 & Diaphragmatic Hernia \\
\hline $\begin{array}{l}\text { N.W. } \\
\text { M.H. } \\
\text { B.S. } \\
\text { B.P. } \\
\text { E.O. } \\
\text { E.E. } \\
\text { S.D. } \\
\text { R.Y. } \\
\text { E.H. }\end{array}$ & $\begin{array}{l}5 \\
4 \\
2 \\
5 \\
4 \\
5 \\
3 \\
6 \\
4\end{array}$ & $\begin{array}{r}7 \\
8 \\
14 \\
3 \\
6 \\
4 \\
4 \\
4 \\
10\end{array}$ & $\begin{array}{l}174 \\
122 \\
150 \\
120 \\
162 \\
110 \\
130 \\
144 \\
138\end{array}$ & $\begin{array}{l}155 \\
110 \\
120 \\
130 \\
164 \\
122 \\
120 \\
140 \\
144\end{array}$ & $\begin{array}{l}\overline{34 \cdot 2} \\
8 \cdot 9 \\
16 \\
15 \cdot 5 \\
\overline{12 \cdot 7} \\
11 \cdot 5\end{array}$ & $\begin{array}{l}17 \\
24 \cdot 4 \\
7 \cdot 3 \\
13 \cdot 6 \\
9 \cdot 7 \\
33 \\
14 \\
3 \cdot 9 \\
12 \cdot 5\end{array}$ & $\begin{array}{l}\frac{\bar{z}}{30} \\
\frac{30}{35}\end{array}$ & $\begin{array}{l}\text { Duodenal Atresia } \\
\text { Much peritoneal exudate } \\
\text { Much peritoneal exudate } \\
\text { Much peritoneal exudate } \\
\text { Much peritoneal exudate } \\
\text { Much peritoneal exudate } \\
\text { Blood spilt on towels }\end{array}$ \\
\hline $\begin{array}{l}\text { B.M. } \\
\text { P.T. } \\
\text { D.W. } \\
\text { P.C. } \\
\text { L.V. }\end{array}$ & $\begin{array}{l}5 \\
6 \\
7 \\
7 \\
5\end{array}$ & $\begin{array}{r}7 \\
9 \\
14 \\
5\end{array}$ & $\begin{array}{l}175 \\
152 \\
120 \\
112 \\
114\end{array}$ & $\begin{array}{l}165 \\
146 \\
116 \\
100 \\
138\end{array}$ & $\begin{array}{c}19 \cdot 1 \\
37.5 \\
1.8 \\
12.5 \\
-\end{array}$ & $\begin{array}{r}24 \cdot 1 \\
28 \cdot 9 \\
1.6 \\
8 \cdot 5 \\
3 \cdot 5\end{array}$ & $\begin{array}{l}\bar{z} \\
\bar{z}\end{array}$ & $\begin{array}{l}\text { Extrinsic Duodenal Obstruction } \\
\text { Blood spilt on towels } \\
\text { Much peritoneal exudate }\end{array}$ \\
\hline W.E. & 5 & 7 & 165 & 125 & 137 & 86 & 85 & $\begin{array}{l}\text { Small Intestinal Atresia } \\
\text { Gangrenous intestine, much peritoneal } \\
\text { exudate }\end{array}$ \\
\hline $\begin{array}{l}\text { D.C. } \\
\text { L.W. } \\
\text { L.W. } \\
\text { S.P. } \\
\text { J.A. }\end{array}$ & $\begin{array}{l}8 \\
4 \\
5 \\
7 \\
5\end{array}$ & $\begin{array}{r}7 \\
12 \\
4 \\
12 \\
7\end{array}$ & $\begin{array}{r}138 \\
100 \\
98 \\
97 \\
98\end{array}$ & $\begin{array}{r}142 \\
90 \\
114 \\
123 \\
85\end{array}$ & $\begin{array}{l}\overline{34 \cdot 5} \\
\overline{18 \cdot 1} \\
-\end{array}$ & $\begin{array}{l}37 \\
25 \\
31 \\
10 \\
83\end{array}$ & $\begin{array}{r}60 \\
100 \\
60 \\
60\end{array}$ & $\begin{array}{l}\text { Much peritoneal exudate } \\
\text { Much peritoneal exudate } \\
\text { Much peritoneal exudate } \\
\text { Much peritoneal exudate } \\
\text { Much peritoneal exudate }\end{array}$ \\
\hline $\begin{array}{l}\text { P.R. } \\
\text { T.M. } \\
\text { M.S. } \\
\text { S.D. } \\
\text { G.M. }\end{array}$ & $\begin{array}{l}6 \\
6 \\
6 \\
7 \\
6 \\
\end{array}$ & $\begin{array}{r}8 \\
10 \\
15 \\
3 \\
15\end{array}$ & $\begin{array}{l}150 \\
166 \\
100 \\
130 \\
102\end{array}$ & $\begin{array}{l}135 \\
164 \\
156 \\
120\end{array}$ & $\begin{array}{l}46 \\
67 \\
33 \cdot 5 \\
40 \cdot 6 \\
\end{array}$ & $\begin{array}{l}24 \cdot 5 \\
29 \\
25 \\
26 \cdot 8\end{array}$ & $\begin{array}{l}50 \\
40 \\
40 \\
40 \\
60\end{array}$ & $\begin{array}{l}\text { High Rectal Atresia } \\
\text { Much peritoneal exudate } \\
\text { Much peritoneal exudate } \\
\text { Much peritoneal exudate } \\
\text { Much peritoneal exudate }\end{array}$ \\
\hline $\begin{array}{l}\text { J.L. } \\
\text { R.H. } \\
\text { P.L. } \\
\text { D.H. } \\
\text { S.M. } \\
\text { G.S. } \\
\text { C.F. } \\
\text { P.K. }\end{array}$ & $\begin{array}{l}8 \\
6 \\
5 \\
8 \\
4 \\
6 \\
4 \\
6\end{array}$ & $\begin{array}{r}3 \\
7 \\
10 \\
1 \\
2 \\
13 \\
5 \\
12\end{array}$ & $\begin{array}{l}115 \\
102 \\
134 \\
156 \\
172 \\
150 \\
156 \\
132\end{array}$ & $\begin{array}{l}112 \\
98 \\
134 \\
152 \\
148 \\
138 \\
152 \\
142\end{array}$ & $\begin{array}{l}1 \overline{2 \cdot} \cdot 5 \\
2 \overline{2} \\
18 \cdot 6 \\
17 \cdot 2 \\
3 \overline{5}\end{array}$ & $\begin{array}{r}5 \cdot 7 \\
8 \cdot 5 \\
4 \cdot 5 \\
6 \cdot 9 \\
15 \cdot 4 \\
11 \\
42 \\
26\end{array}$ & $\begin{array}{l}\bar{z} \\
\bar{z} \\
\overline{65}\end{array}$ & $\begin{array}{l}\text { Exomphalos } \\
\text { Resection of intestine } \\
\text { Resection of intestine, content spilt } \\
\text { Resection of intestine, content spilt } \\
\text { Resection of intestine, content spilt }\end{array}$ \\
\hline $\begin{array}{l}\text { G.H. } \\
\text { D.H. } \\
\text { L.R. } \\
\text { L.R. }\end{array}$ & $\begin{array}{l}5 \\
8 \\
7 \\
8\end{array}$ & $\begin{array}{l}7 \\
9 \\
4 \\
1\end{array}$ & $\begin{array}{r}123 \\
106 \\
78 \\
87\end{array}$ & $\begin{array}{r}132 \\
120 \\
94 \\
136\end{array}$ & $\frac{11}{139}$ & $\begin{array}{l}8 \cdot 4 \\
13 \\
16 \\
91\end{array}$ & $\begin{array}{r}30 \\
50 \\
40 \\
165\end{array}$ & $\begin{array}{l}\text { Obstruction of Bile Ducts } \\
\text { Much peritoneal exudate } \\
\text { Much peritoneal exudate } \\
\text { Much peritoneal exudate, partial hepat- } \\
\text { ectomy }\end{array}$ \\
\hline $\begin{array}{l}\text { A.M. } \\
\text { A.P. } \\
\text { C.B. }\end{array}$ & $\begin{array}{l}5 \\
7 \\
8 \\
\end{array}$ & $\begin{array}{l}14 \\
14 \\
15\end{array}$ & $\begin{array}{r}146 \\
138 \\
62 \\
\end{array}$ & $\begin{array}{r}162 \\
118 \\
78\end{array}$ & $\begin{array}{r}1 \cdot 7 \\
10 \cdot 4 \\
-\end{array}$ & $\begin{array}{l}1 \cdot 4 \\
12 \cdot 7 \\
76\end{array}$ & $\overline{\overline{95}}$ & $\begin{array}{l}\text { Tumours } \\
\text { Sacro-coccygeal tumour } \\
\text { Ganglio-neuroma, blood spilt on towels } \\
\text { Cystic hygroma, lymphatic fluid spilt }\end{array}$ \\
\hline $\begin{array}{l}\text { N.M. } \\
\text { L.B. }\end{array}$ & $\begin{array}{l}4 \\
4\end{array}$ & $\begin{array}{r}4 \\
12\end{array}$ & $\begin{array}{r}103 \\
69\end{array}$ & $\begin{array}{r}100 \\
78\end{array}$ & $\begin{array}{l}1 \cdot 7 \\
9 \cdot 8\end{array}$ & $\begin{array}{l}1 \\
8\end{array}$ & $\overline{55}$ & $\begin{array}{l}\text { Irreduceable Hernia } \\
\text { Blood given for anaemia }\end{array}$ \\
\hline $\begin{array}{l}\text { R.J. } \\
\text { L.M. } \\
\text { L.N. } \\
\text { P.H. }\end{array}$ & $\begin{array}{l}9 \\
8 \\
8 \\
6\end{array}$ & $\begin{array}{r}14 \\
10 \\
5\end{array}$ & $\begin{array}{r}87 \\
110 \\
138 \\
121 \\
\end{array}$ & $\begin{array}{r}82 \\
111 \\
110 \\
96\end{array}$ & $\begin{array}{l}71 \\
28 \cdot 2 \\
62 \\
-\end{array}$ & $\begin{array}{l}70 \\
13 \\
63 \\
55\end{array}$ & $\begin{array}{l}50 \\
50 \\
45\end{array}$ & $\begin{array}{l}\text { Genito-Urinary Operations } \\
\text { Ureterocoele } \\
\text { Hydrocolpos, mucoid fluid spilt } \\
\text { Bladder diverticulum, colostomy } \\
\text { Nephrectomy }\end{array}$ \\
\hline $\begin{array}{l}\text { M.G. } \\
\text { N.T. } \\
\text { W.G. } \\
\text { D.H. } \\
\text { M.L. }\end{array}$ & $\begin{array}{l}7 \\
7 \\
7 \\
6 \\
6\end{array}$ & $\begin{array}{l}4 \\
8 \\
8 \\
3\end{array}$ & $\begin{array}{l}146 \\
176 \\
148 \\
134 \\
142\end{array}$ & $\begin{array}{l}143 \\
148 \\
136 \\
136 \\
124\end{array}$ & $\begin{array}{l}58.7 \\
58 \cdot 5 \\
61.6 \\
35\end{array}$ & $\begin{array}{l}39 \cdot 7 \\
21 \cdot 4 \\
56 \\
35 \\
27\end{array}$ & $\frac{10}{\frac{10}{60}}$ & $\begin{array}{l}\text { Meningo-myelocoele } \\
\text { C.S.F. spilt } \\
\text { C.S.F. spilt } \\
\text { C.S.F. spilt } \\
\text { C.SF. spilt } \\
\text { C.S.F. spilt }\end{array}$ \\
\hline c.s. & 8 & 1 & 75 & 66 & - & 940 & 870 & Aneurysm of lliac Arterv \\
\hline
\end{tabular}

$(100 \%$ Haemoglobin $=14 \cdot 8 \mathrm{~g}$. 
amount of tissue fluids in neonates, but the main reason is undoubtedly the quantities of fluids other than blood (peritoneal exudate, cerebrospinal fluid, intestinal contents, etc.) which frequently invalidated the results in our gravimetric estimations. So constantly did we encounter this difficulty that we not only found it often impossible to perform gravimetric studies, but we are now of the opinion that in newborn babies estimation of the blood loss by weighing is not reliable.

Blood spilt on operation towels, gowns, etc., can only be estimated colorimetrically. When investigating adults this slight inaccuracy in the gravimetric estimation might not be of much consequence, but the small amounts of blood loss encountered in neonatal surgery make it imperative to include this spilt blood in the final calculation. The blood of the newborn infant has a very high haemoglobin content. This greatly facilitates colorimetric estimations of the blood loss, as even small quantities of blood will deeply stain the water used for rinsing the swabs. If the gravimetric method is used when estimating the blood loss of newborn infants, the small weight of the blood loss and the relatively large weight of the operation swabs introduces a considerable error. In adults, where every swab is soaked with blood, this error is negligible. These considerations have led us to employ the colorimetric method to the exclusion of the gravimetric technique. This means that the amount of blood lost can only be measured at the end of the operation and that intermediate readings are impossible. However, unless one uses machine-cut swabs of constant weight it is not feasible to obtain intermediate readings using the gravimetric technique and there is then no advantage in using this method.

The colorimetric method for estimating blood loss is a little tedious to perform and at first we had great hopes that the pre- and post-operative haemoglobin estimation of the patient's blood might be a rough guide for estimating blood loss. A study of Table 1 will show, however, that there is no close relation between blood loss and the haemoglobin readings. This is not surprising as the haemoglobin concentration depends on many variable factors such as temperature, shock, dehydration. In this connexion it is interesting to note that Coller et al. (1944) and Crook, Iob and Coller (1946) investigated the relationship between the blood lost and the changes in the haematocrit, haemoglobin and plasma protein concentration before and after operation on adults. They came to the conclusion that there was no correlation between the blood loss and changes in the patient's blood values.
Average Blood Loss in Different Types of Operation. A glance at Table 1 reveals that the blood loss during the same type of operation varies considerably. The variations are greater than those found in adults (Lenahan, Spitz and Metcalf, 1948). This is rather surprising as all the operations under discussion were performed by two surgeons employing closely similar techniques. When discussing a specific operative procedure on a newborn baby it is not easy to give an average figure for the blood loss.

In thoracotomies for oesophageal atresia, the blood loss is as a rule moderate and only occasionally rises to over $20 \mathrm{ml}$. The same observation holds good for laparotomies for intestinal obstruction unless the intestine has to be resected, when nearly always a considerable amount of blood is lost. In addition there is gangrene of the bowel and considerable extravasation of blood into the intestinal lumen in several of these cases.

For the condition of high rectal atresia, we approach the blind rectum through an abdominal incision, resect it, and pull the sigmoid colon down to the peritoneum by a combined abdominoperitoneal approach. As can be observed from Table 1 the blood loss accompanying this operation is usually quite considerable, from 30 to $50 \mathrm{ml}$.

Exploration of the bile ducts for congenital obstruction is not accompanied by excessive blood loss. In one case, when, because of the absence of all external bile ducts, we attempted a Longmire type of operation, partial hepatectomy and hepatojejunostomy, the blood loss was great (Table 1).

The blood loss during operation for tumours depends of course very much on the size and type of the growth. Only one large tumour was included in this series.

The blood loss for genito-urinary operations and operations on myelo-meningocoeles has been considerable.

The last case in Table 1 has to be mentioned. An enormous mycotic aneurysm of the right common iliac artery had to be extirpated. There was torrential bleeding and during the operation the patient lost an amount of blood nearly three times her total blood volume. The blood was replaced as it was lost. The patient stood the operation well and made a good recovery, demonstrating the remarkable recuperative power of these young babies.

How Accurately Should Blood be Replaced? The results of the present investigation, some theoretical considerations mentioned above, as well as our clinical experience when operating on over 200 
neonates during the last four years, have led us to the conclusion that a blood loss of under 20 to $25 \mathrm{ml}$. can be ignored. There are two exceptions to this rule, namely, (1) in very small premature babies, especially those weighing $4 \mathrm{lb}$. and under, even small amounts of blood lost should be replaced; (2) in operations for oesophageal atresia which are often associated with extensive dissection in the mediastinum and considerable shock. In our experience the babies do well with a blood transfusion considerably in excess of the blood loss and usually we give them an excess of 35 to $50 \mathrm{ml}$. of blood.

As we were only able to ascertain the exact amount of blood lost at the end of the operation, we had to rely to a certain extent on our clinical judgment when transfusing these babies. It will be seen from Table 1 that we tended to over-transfuse rather than under-transfuse our patients. This is surprising as in adults the opposite is usually true. Blain (1929), Coller and Maddock (1932) and Pilcher and Sheard (1937) pointed out that in adults the estimated blood loss is nearly always considerably less than the blood loss actually measured.

It has been our experience that a blood transfusion which moderately exceeds the quantity of blood lost is not injurious to the infant, and is in fact in many instances beneficial. We are convinced that this slight over-transfusion has been one of the causes in lowering our operative mortality. Although we cannot offer any satisfactory explanation, it must be remembered that the haemoglobin concentration of the blood of these infants is very high and that they have the power to destroy large numbers of red blood corpuscles with great ease in the first few days of life.

If at the end of the operation we measure the blood loss and find that we have transfused an inadequate amount of blood, we do not remove the patient from the operation table but continue the transfusion until we have replaced the blood loss.

In conclusion it should be stressed that many of the extensive operations now performed on newborn babies are accompanied by a considerable blood loss and no operation should therefore be contemplated without having an intravenous infusion running, which can be changed over to blood at a moment's notice. The initial high haemoglobin concentration of these babies is no bar to transfusion. It appears that a loss of more than 20 to $25 \mathrm{ml}$. of blood requires replacement transfusion.

I should like to thank Dr. E. Hall and the staff of the Haematology Department for their help in carrying out these investigations. I am grateful to Professor N. B. Capon and Miss Isabella Forshall for their valuable advice.

Baronofsky, I. D., Treloar, A. E. and Wangensteen, O. H. (1946). Surgery, 20, 761.

Blain, A. W. (1929). Ann. Surg., 89, 917.

Bonica, J. J. and Lyter, C. S. (19531). Amer. J. Surg., 81, 496.

Coller, F. A., Crook, C. E. and Iob, V. (1944). J. Amer. med. Ass., 126, 1.

Coller, F. A., and Maddock, W. G. (1932). J. Amer. med. Ass., 99, 875. Crook, C. E., Iob, V. and Coller, F. A. (1946). Surg., Gynec. Obstet., $82,417$.

Gatch, W. D. and Little, W. D. (1924). J. Amer. med. Ass. 83, 1075. Lenahan, N. E., Spitz, T. A. and Metcalf, D. W. (1948). Arch. Surg., Chicago, 57, 435.

Leriche, R. and Vasilaros, E. (1939). Mém. Acad. Chir., Paris, 65, 1242 .

Mollison, P. L., Veall, N. and Cutbush, M. (1950). Archives of Disease in Childhood, 25, 242.

Pilcher, F. and Sheard, C. (1937). Proc. Mayo Clin., 12, 209.

Wangensteen, O. H. (1942). Minn. Med., 25, 783.

White, M. L. and Buxton, R. W. (1942). J. thorac. Surg., 12, 198. 